Başvuru : 25.08.2016

Kabul : :26.12.2016

\title{
Serbest Bölgelerin Dış Ticarete Etkileri: Türkiye Üzerine ARDL Modeli île Ampirik Bir Uygulama ${ }^{1}$
}

Serbest Bölgelerin Dış Ticarete Etkileri: Türkiye Üzerine ARDL Modeli ile Ampirik Bir Uygulama

Öz

Serbest bölgeler, ülkelerin dış ticarette avantaj sağlamak için kurduğu bölgelerdir. Teoride, serbest bölge ticaretinin artması durumunda ülke dış ticaretinin bundan olumlu etkilenmesi beklenmektedir. Dolayısıyla bu çalışmada Türkiye'de serbest bölgelerin ticareti ile ülke dış ticareti arasındaki ilişki ARDL modeli kullanılarak ampirik olarak araştırılmaktadır. 2000:01-2015:12 dönemini kapsayan analizde hem kısa dönemde hem de uzun dönemde ilişkinin varlığı tespit edilmiştir. Buna göre, kısa dönemde serbest bölge ithalatındaki \%1'lik değişme Türkiye'nin ithalatını $\% 0,12$ ve serbest bölge ihracatındaki \%1'lik değişme Türkiye'nin ihracatını \%0,47 artırırken, uzun dönemde serbest bölge ithalatı ile Türkiye'nin ithalatı arasında anlamlı bir ilişki bulunmamakta, ancak serbest bölge ihracatındaki \%1'lik değişme Türkiye'nin ihracatını \%0,14 artırmaktadır. Elde edilen bulgular, serbest bölgelerin özellikle Türkiye'nin ihracatına önemli katkılar sağladığı yönündedir.
The Impact of Free Zones on Foreign Trade: An Empirical Application by using ARDL Model on Turkey

Abstract

Free trade zones are established to gain advantage in foreign trade. In theory, it is expected to see a positive impact in foreign trade if there is an increase in free trade zones' trade. Thereby, this study examines the relationship between free trade zones and foreign trade of Turkey empirically by using ARDL model. Existence of said relationship has been confirmed for both long and short terms for 2000:01-2015:12 period. Hereunder, in the short term $1 \%$ change in import of free trade zones increase Turkey's import by $0,12 \%$ while $1 \%$ change in export of free trade zones increase Turkey's export by $0,47 \%$. In the long term, no meaningful relationship has been found between imports of free trade zones and Turkey's import rate however, $1 \%$ change in export of free trade zones increases Turkey's export by $0,14 \%$. Informations obtained shows that free trade zones contribute greatly specifically to the export of Turkey.
Anahtar Kelimeler: Serbest Bölgeler, Eşbütünleşme, ARDL Modeli, Dış Ticaret
Keywords: Free Zones, Cointegration, ARDL model, Foreign Trade

\section{Giriş}

İktisadi kalkınmanın sağlanmasında dış ticaretin önem kazanması kronolojik olarak genellikle Merkantilizm dönemi ile başlatılır. Daha sonraları klasik iktisat yaklaşımlarının geliştirilmesiyle birlikte, serbest dış ticaret kuramlarının dünya ekonomik düzeninde büyük oranda kabul görmesi ve devamında dünya ekonomilerinin küreselleşme çabası ülkelerin karşılıklı olarak birbirlerinin mallarına olan talebini de artırmıştır. Küreselleşen uluslararası ticaretin ülke ekonomileri üzerindeki olumlu etkilerinin fark edilmesi araştırmacıları sürekli olarak yeni arayışlara yönlendirmiş ve dış ticarette daha avantajlı olabilmenin farklı yolları ve araçları araştırılmıştır. Bu bağlamda uluslararası ticaretin getirilerinden daha fazla faydalanmak, refah seviyesini yükseltmek, ülkenin kalkınmasında sürekliliği sağlamak ve yurt dışından ithal edilen ürünlerin yurt içinde üretimini gerçekleştirmek isteyen ülkeler giderek artan oranda dövize

\footnotetext{
${ }^{1}$ Bu çalışma Yrd. Doç. Dr. Abidin Öncel danışmanlığında hazırlanan "Serbest Bölgelerin Dış Ticarete Etkileri: Türkiye Üzerine Ampirik Bir Uygulama" başlıklı yüksek lisans tezinden yararlanılarak hazırlanmıştır.

${ }^{2}$ Yrd. Doç. Dr., Sakarya Üniversitesi SBF, i̇ktisat Bölümü. aoncel@sakarya.edu.tr

${ }^{3}$ Yıldız Teknik Üniversitesi SBE, İktisat ABD. sukrucandemirtas@gmail.com
} 
intiyaç duymuşlar ve bu nedenle döviz kazandırıcı ticaretin arttırılması yönünde farklı politikalar geliştirmişlerdir. Ancak ülkeler iç piyasayı ve üreticisini korumak amacıyla zaman zaman çeşitli araçlarla dış ticareti kısıtlayıcı önlemler de almışlardır. Buna rağmen, dış kredi bulma imkânlarının oldukça sınırlı olduğu da dikkate alınırsa, ülkeler hızla her türlü döviz kazandırıcı işlemlere ağılık vermek ve kısa vadede döviz kazanmak zorundadırlar. Bu nedenle araştırmacılar ülkelerin karşılıklı olarak koydukları ticaret kısıtlamalarından etkilenmeyen yeni alanlar araştırmışlar ve bu bağlamda serbest bölgeler bu amacı gerçekleştirmede önemli bir araç olarak gündemdeki yerini giderek artırmıştır (Bağrıaçık, 1983: 24).

ilk serbest bölge uygulamaları aslında oldukça eski tarihlere dayanmaktadır. Antik çağdan beri hükümetler, imparatorluklar ve krallıklar, tüccarlara ve yatırımcılara normal ihracatithalat vergi rejimleri ve yönetmeliklerden ayrıcalık tanıyan özel siteler kurmuşlardır. Orta çağ boyunca Delos, Venedik, Cenova ve Marsilya gibi Akdeniz havzasında yer alan merkezlerde toplanmış bu gibi uygulamalar 19.yüzyıla gelindiğinde Orta Asya'ya yayılmıştır. Fakat 20.yüzyılın ikinci yarısına gelininceye kadar, iktisadi kalkınmanın önemli bir aracı olarak görülen anlayışta "serbest bölge" uygulamalarına pek rastlanmamaktadır (OECD, 2016). Daha sonraları ise dış ticareti artırmanın ve de iktisadi kalkınmayı sağlamanın önemli bir aracı olarak çok sayıda serbest bölgenin kurulduğu gözlenmektedir.

Serbest bölgeler, "ülkede geçerli ticari, mali ve iktisadi alanlara ilişkin hukuki ve idari düzenlemelerin uygulanmadığı veya kısmen uygulandığı, sınai ve ticari faaliyetler için daha geniş teşviklerin tanındığı ve fiziki olarak ülkenin diğer kısımlarından ayrılan yerler" (T.C. Ekonomi Bakanlığı, 2016a) şeklinde tanımlanmaktadır. Genel itibariyle serbest bölgeler, serbest ticaret bölgesi, serbest üretim bölgesi, serbest finansal bölgeler, serbest tüketim bölgesi ve transit bölgeler olmak üzere beş alt başlıkta incelenmektedir. Söz konusu bölgeler, ülke istihdamını, döviz birikimini, ithalatı ve yabancı sermaye girişini olumlu yönde etkilerken; vergi kaybı, ithalat baskısı, yasadışı faaliyetlerde artış riski, kaçakçılık, yerli firmalara rakip olma, yatırımların olumsuz dağılması, tekelleşme ve sosyal yapının bozulması gibi olumsuz etkilere de sahiptirler. Serbest bölgelerin uygulayıcı ülkeye katkılar sunması açısından olumlu etkilerinin daha baskın çıkması gerekmektedir.

Dış ticaretin gerçekleştirilmesinde, hem ülkeye hem de üretici firmalara sağladığı avantajlar nedeniyle, serbest bölgeler oldukça önemli bir yere sahiptir. Gerek firmalara sağladığı avantajlarla ki bunların en önemlisi vergi avantajıdır ve gerekse devletin destek teşvikleri sayesinde serbest bölgelerde bulunmanın cazibesi her geçen gün daha da artmaktadır. Maliyeti de düşüren bu sistem sayesinde firmalar bölge içine getirdikleri ithal ürünler için vergi ödemezken, bölge dışına çıkan ürünlerden daha kolay kâr elde edebilmekte ve aynı zamanda belirli şartlarda devletin verdiği teşvikler sayesinde ticaret yaşamlarını ve yatırımlarını daha güvenli bir şekilde gerçekleştirebilmektedir. Aynı zamanda ülke içinde sosyal ve politik istikrarın sağlanmış olması ve millileştirme açısından güvence verilmesi, kârların transfer edilme hakkının verilmesi, çifte vergilendirmenin ortadan kaldırılmış olması, daha düşük ücret ve aynı zamanda sendikal hakların kısıtlanmış olması, yatırımcılara sağlanan fiziki altyapı gibi cazip etkenler sayesinde ülkeye yabancı sermaye çekilebilmektedir. Serbest bölgeler, ülkenin döviz girdilerini arttırarak ödemeler dengesi açıklarını kapatma açısından da avantajlar sağlar. Bölgelerden gerçekleştirilen ihracata ilave olarak faaliyet gösteren her türlü kuruluşun kâr transferleri, elde edilen kira ve harçların gelirleri, bankacılık hizmetlerinin gelirleri, işçi ve teknik eleman ücretleri, taşıma gelirleri gibi faaliyetlerle ülkenin döviz girdileri arttırılmakta ve ödemeler dengesinin sağlanmasına önemli katkılar sunulmuş olmaktadır (Uçkun vd., 2005). 
Serbest bölgeler yukarıda yer alan açıklamalardan da anlaşılacağı üzere sağladığı avantajlarla dış ticareti etkileyebilmektedir. Serbest bölgelerin dış ticaret üzerindeki etkilerini ihracat üzerindeki etkiler ve ithalat üzerindeki etkiler şeklinde ayrı ayrı değerlendirmek mümkündür. Buna göre ihracat üzerindeki etkileri genellikle ana ülkeden serbest bölgelere gerçekleşen hammadde, mamul, yarı mamul ve diğer girdi ihracatı noktalarına yoğunlaşmaktadır. İhracat işlemlerindeki istikrar ve kolaylıklar, reeksport da denilen ve yurtdışından ithal edilen malların başka bir ülkeye yeniden ihracatının yapılarak bu imkândan ihracatçıların faydalandırılıyor olması, ihraç edilebilecek malların serbest bölgelerde daha kolaylıkla dış pazar gereklerine uygun hale getirilebilmesi, her tür ihracat piyasalarının daha iyi tanınması, talep analizi ve buna göre ürün geliştirme çabalarına girişilmesi (İncekara, 1986: 30-32) ve ayrıca serbest bölgeler ile burada faaliyette bulunan firmaların temel ihtiyaçları olan elektrik, su ve diğer hizmetlerin ana ülkeden sağlanıyor olması (Tümenbatur, 2012: 344) ülke ihracatını etkileyen temel hususlardır. İthalat üzerindeki etkileri ise, daha çok yurt içinde ihtiyaç duyulan her türlü mal ve girdinin serbest bölgelerden daha kolay bir şekilde temin edilebilmesi noktasına yoğunlaşmaktadır. Buna göre, gerek ithalatçı ve gerekse ihracatçı şirketlerce serbest bölgelere daha önceden getirilerek hazır bulundurulan mal ve girdiler, ihtiyaç duyuldukça küçük partiler halinde ülke içerisine sokulabilmekte ve dolayısıyla bu durum ithalat açısından önemli yararlar sağlamaktadır. Zaman kaybı olmadan malların serbest bölgeye getirilebilmesi ve istendiğinde serbest bölgelerden ithali zaman yönüyle, malı serbest bölgelerde stoklayabilme imkanları stoklama yönüyle, malları yurtiçine ithal ettikçe gümrük ve diğer işlemler için masrafları ödeme zorunluluğunun doğması maliyet yönüyle ve serbest bölgelerin herkese açık olmasının getirdiği rekabet koşullarının kaliteyi arttırması nedeniyle kalite güvencesi yönüyle ithalatçılara önemli avantajlar sağlanmış olmaktadır (Aslan, 2013:32; İncekara, 1986: 32). Hiç kuşkusuz burada belirtilen etkiler aynı zamanda diğer yurtiçi yatırımları da olumlu etkilemekte ve ülkenin dış ticaret kapasitesini daha da genişletmektedir.

Türkiye'de serbest bölge kurma sürecine göz atıldığında, 24 Ocak 1980 kararları sonrasında dışa açık ve ihracata dayalı büyüme politikalarının uygulanmaya başlanmasıyla eş zamanlı olarak, serbest bölge kurma fikrinin hayata geçirilmiş olduğu görülmektedir. 1985 yılında yürürlüğe giren 3218 sayılı Serbest Bölgeler Kanunu ile birlikte 1987 yılından bu yana ülke genelinde 21 serbest bölge kurulmuştur. İlgili kanunun 1. Maddesinde belirtildiği üzere serbest bölgelerin kuruluş amacı "ihracata yönelik yatırım ve üretimi teşvik etmek, doğrudan yabancı yatırımları ve teknoloji girişini hızlandırmak, işletmeleri ihracata yönlendirmek ve uluslararası ticareti geliştirmek" (T.C. Ekonomi Bakanlığı, 2016b) şeklindedir. İhracata dayalı büyüme politikalarının uygulanması sonucunda Türkiye'nin, tarım ürünleri ihracatçısı, sanayi ürünleri ithalatçısı bir ülke konumundan günümüzde ihracatının büyük bir kısmını sanayi ürünlerinin oluşturduğu bir ülke haline geldiği görülmektedir. Bu dönüşümde serbest bölgelerin önemli katkılar sunduğu düşünülmektedir.

Yukarıdaki açıklamalardan da hareketle, bu çalışmada serbest bölgelerin dış ticareti ile Türkiye'nin dış ticareti arasındaki ilişki ekonometrik zaman serileri metodolojisi ile ampirik olarak incelenmeye çalışılmaktadır. Bu bağlamda çalışmanın bundan sonraki kısımlarında öncellikle teorik ve ampirik literatür özetlenmekte ve devamında söz konusu iki değişken arasında ilişki ARDL yöntemi kullanılarak eşbütünleşme analizine tabi tutulmaktadır. Çalışmanın sonuç kısmında ise araştırma bulgularının teori ile uyumluluğu kısaca tartışımakta ve çalışma sonlandırılmaktadır. 


\section{Teorik ve Ampirik Literatür}

Yapılan literatür araştırmasında, serbest bölgelerin ${ }^{4}$ dış ticaret üzerindeki etkilerini inceleyen çalışmaların çoğunluğunda ampirik uygulama kısımlarının mevcut olmadığı görülmüştür. Bu tür çalışmalarda genellikle veriler tablolar halinde sunulmuş ve ekonometrik analiz yapılmadan sadece verilerin yorumlanması yöntemi kullanılmıştır. Ampirik analizin kullanıldığı az sayıda çalışmada ise ARDL modelinin kullanıldığı herhangi bir çalışmaya rastlanmamıştır. Dolayısıyla bu çalışma, kullanılan yöntem itibariyle, alanla ilgili boşluğu doldurmada ilk sayılabilecek çalışmalardan biri olarak değerlendirilebilir. Serbest bölgelerin dış ticaret üzerindeki etkilerini doğrudan veya dolaylı olarak inceleyen çalışmaların bir kısmı aşağıda literatür incelemesi kapsamında değerlendirilmektedir.

Khalifa (tarihsiz), serbest bölgelerin Mısır'ın dış ticareti ve yabancı yatırımlar üzerindeki etkilerini 1992-2001 dönemi için analiz ettiği çalışmasında, serbest bölgelerden gerçekleşen ihracatın, yerel pazarlardan gerçekleştirilen ithalattan 5 kat daha fazla olduğunu, ancak bu ihracatın büyük çoğunluğunun dış pazarlara yapılmış olmasından dolayı dış ticaret dengesine olumlu katkılar sunduğunu belirtmiştir. Çalışmada ayrıca serbest bölgelerin yerel pazarlardan gerçekleştirdiği ithalatın (bu aynı zamanda yerel pazarların ihracatıdır), söz konusu bölgelerin gerçekleştirdiği ihracattan daha önemli olduğuna da vurgu yapılmıştır.

Jayanthakumaran (2003), seçilmiş 6 Asya ülkesi (Güney Kore, Malezya, Sri Lanka, Çin, Endonezya ve Filipinler) üzerine gerçekleştirdiği çalışmada, serbest bölgelerin performanslarını fayda-maliyet analizi çerçevesinde ölçmüş ve Filipinler dışında diğer 5 ülkede serbest bölgelerin ekonomik olarak etkin olduklarını ve fırsat maliyetlerinin üzerinde bir getiri sağladıklarını tespit etmiştir. Çalışmada ayrıca, serbest bölgeler tüm ülkeler için önemli bir istihdam kaynağı olarak tespit edilirken, Güney Kore ve Endonezya'da yerel girişimcileri teşvik etme yönünde de yararlar sağladıkları tespit edilmiştir.

Jenkins (2005), Kosta Rica için Tobit regresyon modeli kullanarak serbest bölgelerin sosyoekonomik etkilerini araştırdığı çalışmada, söz konusu bölgelerin geleneksel ihracat yöntemlerine bağımlılığı azaltmada, ihracat gelirlerini artırmada ve özellikle niteliksiz kadın işgücüne istihdam olanakları sağlamada önemli bir rol üstlendiğini belirlemiştir. Çalışmada ayrıca serbest bölgelerin yabancı sermayeyi çekme noktasında önemli bir politika aracı olduğuna da vurgu yapılmıştır.

Tetsu (2006), gelişmekte olan ülkelerde kurulan serbest bölgelerin etkilerini kırsal veya kentsel alanda geri-bağlantılar kurmaları durumuna göre ayrı ayrı değerlendirdiği teorik çalışmada, söz konusu bölgelerin kentsel alanlarda kurulu bulunan firmalarla geri-bağlantılar kurmaları durumunda ülkenin gelirini arttırdığını ve aynı zamanda kentsel işsizliği azalttığını oluşturduğu genel denge modeli çerçevesinde açıklamıştır.

\footnotetext{
${ }^{4}$ Yerli ve yabancı literatürde serbest bölgeler (free zones) ile benzerlik gösteren bazı kullanımlar, serbest ticaret bölgeleri (free trade zones), dış ticaret bölgeleri (foreign trade zones), özel ekonomik bölgeler (special economic zones), ihracat işleme bölgeleri (export processing zones), serbest limanlar (free ports), ekonomik ve teknolojik gelişme bölgeleri (economic and technological developmend zones), endüstriyel gelişme bölgeleri (industrial development zones), ticaret geliştirme bölgeleri (trade development zones) şeklinde belirtilebilir (wikipedia.com; Teyler ve Negrete, 2009: 1-2; Vicens-Feliberty, 2013:53-54; Jayanthakumaran, 2003:52). Literatür özeti verilirken benzer kullanımlar serbest bölge şeklinde ifade edilmiştir.
} 
Teyler ve Negrete (2009), 1961-1999 dönemi için panel veri analizi kullanarak 87 ülke (kapsamlı verilerin mevcut olduğu gelişmiş ve azgelişmiş ülkeleri kapsayan) üzerine gerçekleştirdikleri çalışmada, ekonomik büyüme ile serbest bölge kullanımı arasında pozitif ve anlamlı bir ilişki bulmuşlardır. Analiz sonuçlarına göre, serbest bölgeleri bir politika aracı olarak kullanan ülkelerde, bu aracı kullanmayanlara nispetle büyüme daha hızlı gerçekleşmektedir. Serbest bölgelerin varlığı durumunda ülkenin ekonomik büyümesi bundan yaklaşık \%0,9 oranında pozitif etkilenmektedir. Söz konusu bölgelerin ekonomik büyümeyi olumlu etkilemesi teknolojik ilerleme ve verimlilik artışlarını kolaylaştırması yoluyla gerçekleşmektedir.

Hao (2010), 1996-2009 dönemi için yıllık verilerle serbest bölge (Waigaoqiao bölgesi) ticareti ile ekonomik büyüme arasındaki ilişkiyi Granger nedensellik testi ve aşamalı regresyon modeli çerçevesinde analiz ettiği çalışmada, serbest bölge ticaretindeki \%1'lik artışın Şangai GSYiH'sını \% 0,223 etkilediği sonucuna ulaşmıştır.

Tiefenbrun (2013), tablolar ve nicel veriler kullanarak ABD üzerine yaptığı çalışmada, serbest bölgelerin ihracat artışı sağlayarak, sanayi rekabetini güçlendirerek ve doğrudan yabancı yatırımları teşvik ederek ülkenin iktisadi büyümesine önemli katkılar sunduğunu belirtmiştir. Serbest bölgelerin örneğin ABD ihracatına 2010 yılında 34,8 milyar \$ katkı sağladığını ve bazı serbest bölge yetkililerinin tahminlerine göre sonraki 10 yıl içerisinde serbest bölgelerdeki imalat faaliyetlerinin 4 kat artacağı ifade edilmiştir. Çalışmada ayrıca, serbest bölgelerden gerçekleşecek ihracatın ABD ekonomisini pozitif etkilemesi için, tıpkı Çin ekonomisinde son yıllarda yapıldığı gibi, bu bölgelerden gerçekleştirilecek ihracatın önemli miktarda arttırılması gerektiği vurgulanmıştır.

Vicens-Feliberty (2013), 2005-2010 dönemi için panel veri analizi kullanarak ABD'de serbest bölgeler ile ihracat yoğunluğu (performansı) arasındaki ilişkiyi incelediği çalışmada, hem mikroekonomik (metropol ve eyalet düzeyinde) hem de makroekonomik (ülke) düzeyde söz konusu iki değişken arasında pozitif ve anlamlı ilişkiler bulmuştur. İhracat yoğunluğunun bağımlı değişken olarak alındığı çalışmada, GSYiH büyüme oranları, reel döviz kurları, ticaret hadleri, aktif serbest bölge sayıları ve serbest bölgelerin gelir üretkenlikleri bağımsız değişkenler olarak seçilmiştir. Çalışmada, serbest bölgelerin olumsuz makroekonomik koşullara sahip bölgelerde, gelirleri artırma, doğrudan yabancı sermayeyi çekme, teknolojinin yayılması ve altyapıyı iyileştirme gibi hususlarla rekabet avantajları sağlamak suretiyle ihracat üzerine olumlu etkiler oluşturduğu vurgulanmıştır. Çalışmanın bulgularına göre ilave bir serbest bölge kurulmasının, ihracat yoğunluğunu \%0,22 oranında pozitif yönde etkilediği tespit edilmiştir. Daha mikro düzeyde gerçekleştirilen analiz sonucunda ise, serbest bölge ihracatında meydana gelecek \%1'lik artış, eyaletlerden ülkenin ihracatına doğru \% 0,0055 ve metropollerden eyaletin ihracatına doğru \%0,0035'lik artışa neden olurken, sadece metropollerden ülkenin ihracatına doğru istatistiksel olarak anlamlı bir ilişkiye rastlanmamıştır.

Siroen ve Yücer (2014), Dünya Ticaret Örgütüne üye 122 ülkenin 2008 yılı verilerini kullanarak, serbest bölgelerin ticaret etkilerini çekim modeli çerçevesinde analiz ettikleri çalışmada, söz konusu bölgelerin korumanın olumsuz etkilerini azaltarak ticaret hacmini arttırdıkları sonucuna ulaşmışlardır. Buna göre, girdi ithalatçısı olarak serbest bölgeler dünyanın geriye kalan kısımlarının ihracatını yükseltmekte ve küresel değer zincirine katkılar sunmuş olmaktadır. Analiz sonuçlarına göre ülkelerin sahip oldukları GSYiH düzeyleri, ülkeler arasındaki mesafe, ortak dil, sömürge geçmişi, gümrük tarifeleri gibi unsurların yanısıra serbest bölgeye sahip bulunmanın da ticarete etkileri bulunmaktadır. 
Türkiye üzerine gerçekleştirilen çalışmalara bakıldığında, oldukça sınırlı sayıda çalışma bulunduğu görülmektedir. Karaduman ve Yıldız (2002), serbest bölge uygulamalarının dış ticarete ve yabancı sermayeye katkılarını Türkiye için sayısal veriler üzerinden değerlendirdikleri çalışmada, Türkiye'de kurulu bulunan serbest bölgelerin dış ticaret hacmine önemli katkılar sunduklarını (incelenen dönem için \%12'lik katkı), ancak yabancı sermaye girişi açısından potansiyellerinin altında kaldıklarını vurgulamışlardır. Uzandaç (2008), 1996-2007 dönemini kapsayan çalışmasında, serbest bölgelerin dış ticaret üzerindeki etkisini VAR analizi ve eşbütünleşme testi yaparak incelemiş, serbest bölge ihracatının, Türkiye ihracatını pozitif yönde etkilediği (serbest bölgelerin ihracatı \%1 artırıldığında Türkiye'nin ihracatı \%0.30 artmaktadır) sonucuna ulaşmıştır. Kavlak (2012), Türkiye'deki serbest bölgelerin ekonomik etkilerini ve serbest bölgelerin kuruluş amaçlarını ne ölçüde gerçekleştirebildiğine ilişkin olarak bölgede faaliyet gösteren firmaların algılarını belirlemeye yönelik çalışmasında, serbest bölgelerin ihracatı uyarıcı etkiler oluşturduğunu, doğrudan yabancı yatırımlarını çekme ve teknoloji transferi yoluyla ülke ekonomisine katkılar sunma potansiyeline sahip olduklarını belirlemiştir. Bakan ve Gökmen (2014), serbest bölgelerin dış ticarete etkilerini Gaziantep Serbest Bölgesi özelinde 2001-2012 verilerini esas alarak değerlendirdikleri çalışmada, söz konusu bölgenin uluslararası ticarete olumlu yönde katkılar yapmasına rağmen, Türkiye'nin diğer bölgelerinde olduğu gibi potansiyelinin altında etkiler oluşturduğuna vurgu yapmışlardır.

Yukarıda yer alan Literatür incelemesi genel olarak değerlendirildiğinde, serbest bölgelerin ülkelerin ekonomik büyümesine ve dış ticaretine değişik kanallardan az ya da çok oranda olumlu katkılar sunduğu söylenebilir. Ancak çalışmamızla doğrudan ilişkili olan çalışma sayısının da oldukça sınırlı sayıda olduğu burada tekrar belirtilmelidir.

\section{Araştırmanın Yöntemi}

Bu çalışmada 2000:01-2015:12 dönemleri için 192 aylık veri kullanılarak Türkiye'deki serbest bölgelerin ihracat ve ithalatının Türkiye'nin dış ticaretini etkileyip etkilemediği analiz edilmektedir. Ülke dış ticareti yalnızca serbest bölgelerden etkilenmediği için modele dış ticareti etkileyen diğer bazı değişkenler de eklenmiştir. 2 farklı model kurulmuş ve ilişkiler ayrı ayrı açıklanmaya çalışımıştır. Kullanılan veriler Türkiye İstatistik Kurumu (TÜiK) ve IMF (International Monetary Fund)'in IFS (International Financial Statistics) veri tabanlarından elde edilmiştir. Ayrıca verilerin tamamı değişen varyans probleminden kaçınmak için logaritmik dönüşümleri alınarak analizlere dahil edilmiştir. Bu bağlamda ilk olarak ADF(1979) ve PP(1988) Birim Kök Testi ve devamında yapısal kırılmaları tespit etmek amacıyla Lee ve Strazicich (2003) Birim Kök Testi gerçekleştirilmiş, devamında ise eşbütünleşme analizi için ARDL yöntemi kullanılmıştır.

\subsection{Durağanlık Testi}

Durağanlık, serilerin belli bir değere yaklaşmasını veya beklenen değerin etrafında dalgalanıyor olmasını ifade etmektedir (Bozkurt, 2007: 27). Durağan olmayan zaman serileriyle yapılan regresyon analizlerinde en küçük kareler yönteminin kullanılması halinde, sahte regresyon sorunu ortaya çıkabilmekte (Granger ve Newbold, 1974: 111-120) ve bu nedenle elde edilen sonuçlar gerçeği yansıtmamaktadır. İki değişken aynı anda ortalamanın altında ve üstünde yer alıyorsa kovaryans pozitif olacaktır. Eğer birinci değişkenin değeri ortalamasının üstünde fakat ikinci değişkenin değeri ortalamasının altında ise ya da tersi durum söz konusu ise kovaryans negatif olacaktır (Sevüktekin ve Nargeleçekenler, 2005: 214) Bir zaman serisinin ortalaması, varyansı ve kovaryansı zaman içerisinde değişmiyorsa zayıf durağanlık olarak tanımlanır (Darnel, 1994: 386). Seriler birinci farklarında durağanlaşmış ise birinci derecede bütünleşik şeklinde adlandırılmaktadır (Kennedy, 2006: 356). 


\subsection{ARDL Yöntemi}

Değişkenler arasındaki uzun dönemli ilişkinin incelenmesi açısından eşbütünleşme testleri uygulanmaktadır. Seviyelerinde durağan olmayan iki veya daha fazla serinin durağan bir bileşimi olduğunu ifade eden eşbütünleşme kavramını test etmek amacıyla literatürde genellikle Engle-Granger ve Johansen testleri kullanılmaktadır. Bu testler, kullanılacak tüm serilerin aynı düzeyde durağan olması koşuluyla kullanılabilmekte ve serilerin farklı durağanlık seviyelerinde olmaları halinde ise geçersiz kalmaktadırlar (Özşahin, 2012: 394). Ancak bu ön koşulu geçersiz kılmak için Peseran ve Pesaran (1997), Shin ve Peseran (1999) ve Pesaran vd. (2001) tarafından sınır testi yaklaşımı geliştirilmiştir. Sınır testi yaklaşımında modelde kullanılacak değişkenlerin düzeyde I(0) ya da birinci farklarında I(1) durağan olup olmaması önem taşımamaktadır (Narayan ve Narayan, 2005: 428-429). Ancak değişkenlerin ikinci farklarında I(2) durağan olmaları ihtimaline karşı sınanmaları gerekmektedir.

ARDL yaklaşımı 3 aşamalı bir süreçten oluşmaktadır. ilk aşamada sınır testi ile değişkenler arasında uzun dönemli bir ilişki olup olmadığı araştırılırken, ilişkinin varlığı şartıyla ikinci ve üçüncü aşamalarda sırasıyla uzun ve kısa dönem katsayılarına ulaşılmaktadır (Narayan ve Smyth, 2006: 337). Testin ilk aşamasında kullanılan kısıtsız hata düzeltme modeli aşağıdaki gibi oluşturulabilir:

$$
\begin{aligned}
& \Delta \mathrm{Y}_{t}=\alpha_{0}+\sum_{\mathrm{i}=1}^{m} \alpha_{1 i} \Delta \mathrm{Y}_{t-i}+\sum_{i=0}^{m} \alpha_{2 i} \Delta \mathrm{X}_{1 t-i}+\ldots+\sum_{\mathrm{i}=0}^{m} \alpha_{k i} \Delta \mathrm{X}_{k t-i}+\alpha_{1} \mathrm{Y}_{t-1}+ \\
& \alpha_{2} \mathrm{X}_{1 t-1}+\ldots+\alpha_{k} \mathrm{X}_{k t-1}+\mathrm{u}_{\mathrm{t}}
\end{aligned}
$$

Gecikme uzunluğunun belirlenmesinden sonra değişkenler arasında eşbütünleşme ilişkisi olup olmadığını gösteren hipotezler model 1'de yer alan değişkenlerin düzey değerlerinin, bir dönem gecikmeli değerlerinin anlamlılı̆ının sınanmasıyla test edilebilir (Yılancı, 2012: 70). Burada test edilen hipotezler aşağıdaki gibidir:

$$
\begin{aligned}
& H_{0}=\alpha_{1}=\alpha_{2}=0 \text { eşbütünleşme yoktur } \\
& H_{1} \neq \alpha_{1} \neq \alpha_{2} \neq 0 \text { eşbütünleşme vardır }
\end{aligned}
$$

Değişkenler arasında eşbütünleşme ilişkisine ulaşılması durumunda, ARDL yaklaşımının ikinci aşaması yani değişkenler arasındaki uzun dönem ilişkisinin analizine geçilebilir. Çalışmada aşağıdaki uzun dönem ARDL modelinden faydalanılmaktadır:

$$
\mathrm{Y}_{\mathrm{t}}=\alpha_{0}+\sum_{\mathrm{i}=1}^{\mathrm{m}} \alpha_{1 \mathrm{i}} \Delta \mathrm{Y}_{\mathrm{t}-\mathrm{i}}+\sum_{\mathrm{i}=0}^{\mathrm{n}} \alpha_{2 \mathrm{i}} \Delta \mathrm{X}_{1 \mathrm{t}-\mathrm{i}}+\cdots+\sum_{\mathrm{i}=0}^{\mathrm{r}} \alpha_{\mathrm{ki}} \Delta \mathrm{X}_{\mathrm{kt}-\mathrm{i}}+\mathrm{u}_{\mathrm{t}}
$$

Değişkenler arasındaki kısa dönem ilişki ise ARDL yöntemine dayanan hata düzeltme modeliyle elde edilebilir:

$$
\Delta \mathrm{Y}_{\mathrm{t}}=\alpha_{0}+\sum_{\mathrm{i}=1}^{\mathrm{m}} \alpha_{1 \mathrm{i}} \Delta \mathrm{Y}_{\mathrm{t}-\mathrm{i}}+\sum_{\mathrm{i}=0}^{\mathrm{n}} \alpha_{2 \mathrm{i}} \Delta \mathrm{X}_{1 \mathrm{t}-\mathrm{i}}+\cdots+\sum_{\mathrm{i}=0}^{\mathrm{r}} \alpha_{\mathrm{ki}} \Delta \mathrm{X}_{\mathrm{kt}-\mathrm{i}}+\mu e c m_{\mathrm{t}-1}+\mathrm{u}_{\mathrm{t}}
$$

Model 3'te yer alan ecm değişkeni, hata düzeltme terimini ifade etmektedir. Söz konusu değişken katsayısının 0 ile -1 arasında gerçekleşmesi, uzun dönemde denge değerine tekdüze bir şekilde yakınlaşmanın söz konusu olduğu anlamına gelmektedir. Katsayının -1 ile -2 değerleri arasında gerçekleşmesi, hata düzeltme sürecinin uzun dönem denge değerleri etrafında azalan dalgalanmalar göstererek dengeye ulaşılabildiğini ve bu değerin pozitif veya -2 'den küçük olması ise, dengeden uzaklaşıldığı anlamına gelmektedir (Alam ve Quazi, 2003: 97). 


\subsection{Birim Kök Testi Sonuçları}

Çalışmada kullanılan değişkenler arasında herhangi bir ilişkinin bulunup bulunmadığı incelenirken, değişkenlerin durağanlık derecelerinin tespit edilmesi, model seçiminde önemlidir. Bu amaçla serilerin durağanlık seviyeleri ilk önce ADF(1979) ve PP(1988) Birim Kök Testi ile ve daha sonra yapısal kırılmaların tespiti için Lee ve Strazicich Birim Kök Testi ile aşağıda incelenmektedir.

\subsubsection{ADF(1979) ve PP(1988) Birim Kök Testi Sonuçları}

ADF(1979) ve PP(1988) birim kök testlerinde sıfır hipotezi serilerin birim köklü olduğunu, alternatif hipotez ise serilerin seviyede durağan olduğunu ifade etmektedir.

Tablo 1: ADF(1979) ve PP(1988) Birim Kök Testi Sonuçları

\begin{tabular}{lllll}
\hline Değişken & ADF - t istatistiği düzey & $\begin{array}{l}\text { ADF - t istatistiği birinci } \\
\text { farkları }\end{array}$ & PP - t istatistiği düzey & $\begin{array}{l}\text { PP - t istatistiği birinci } \\
\text { farkları }\end{array}$ \\
\hline \hline LSBiHR & $-4.764340(0.0001)$ & - & $-4.278539(0.0006)$ & - \\
LSBiTH & $-2.290289(0.1762)$ & $-13.65355(0.0000)$ & $-2.677486(0.0798)$ & - \\
LTRiHR & $-3.704186(0.0048)$ & - & $-2.749974(0.0676)$ & - \\
LTRiTH & $-2.710689(0.0742)$ & - & $-3.059293(0.0314)$ & - \\
LRDK & $-2.281988(0.1789)$ & $-9.258617(0.0000)$ & $-2.402769(0.1423)$ & $-9.010016(0.0000)$ \\
LTRiNDP & $-0.776089(0.8231)$ & $-15.03226(0.0000)$ & $-1.277260(0.6400)$ & $-32.04522(0.0001)$ \\
LWiNDP & $-2.154286(0.2240)$ & $-7.089391(0.0000)$ & $-2.314106(0.1686)$ & $-13.80756(0.0000)$ \\
LiHR_BF & $-1.517068(0.5230)$ & $-8.960810(0.0000)$ & $-1.488760(0.5373)$ & $-9.017754(0.0000)$ \\
LiTH_BF & $-1.560428(0.5009)$ & $-12.34728(0.0000)$ & $-1.601607(0.4798)$ & $-12.86285(0.0000)$ \\
\hline
\end{tabular}

Not: ADF testinde uygun gecikme uzunluğu Schwarz bilgi kriterine göre belirlenmiştir. PP testinde çekirdek (kernel) yöntemi "Barlett kernel" ve bant genişliği (bandwith) "Newey West bandwith" yöntemine göre belirlenmiştir. Parantez içerisindeki değerler, olasılık ( $p$-value) değerlerini göstermektedir.

Tablo 1 ADF(1979) ve PP(1988) Birim Kök Testi sonuçlarını özetlemektedir. Tablo 1'de yer alan birim kök testi sonuçlarına bakıldığında, bazı değişkenlerin seviyede durağan iken, bazılarının ise birinci farkları alındığında durağan oldukları görülmektedir.

\subsubsection{Lee ve Strazicich Birim Kök Testi Sonuçları}

Lee ve Strazicich (2003), temel ve alternatif hipotezlerin her birinde yapısal kırılmaya izin veren alternatif Birim Kök Testi geliştirmişlerdir ${ }^{5}$. Çalışmamızın analiz döneminde iki önemli ekonomik krizin (2001 ve 2008) yaşandığı göz önüne alındığında, kullanılan değişkenlerin yapısal kırılmalara maruz kalmış olabileceği de düşünülerek aşağıda Lee ve Strazicich Birim Kök Testi de gerçekleştirilmiştir.

\footnotetext{
${ }^{5}$ Geniş bilgi için bknz: Lee ve Strazicich, 2003:1082.
} 
Tablo 2: Lee ve Strazicich (2003) Birim Kök Testi Sonuçları

\begin{tabular}{|c|c|c|c|c|c|c|}
\hline \multirow[b]{2}{*}{ Değiş̧kenler } & \multicolumn{3}{|c|}{ Model A } & \multicolumn{3}{|c|}{ Model C } \\
\hline & $\begin{array}{c}\mathrm{T}- \\
\text { istatistik }\end{array}$ & Kırılma Tarihleri & $\begin{array}{c}\text { Kritik Değer- } \\
\text { ler }\end{array}$ & T-istatistik & Kırılma Tarihleri & $\begin{array}{c}\text { Kritik } \\
\text { Değerler }\end{array}$ \\
\hline LSBIHR & -0.8512 & 2002.06-2005.12 & \multirow{14}{*}{$\begin{array}{ll}1 \% & -4.545 \\
5 \% & -3.842 \\
10 \% & -3.504\end{array}$} & $-6.0503 * *$ & 2003.06-2009.01 & \multirow{9}{*}{$\begin{array}{cc}1 \% & -6.41 \\
5 \% & -5.74 \\
10 \% & -5.32\end{array}$} \\
\hline LSBITH & $-4.0827 * *$ & 2002.06-2008.09 & & $-6.8721 * * *$ & $2002.03-2008.10$ & \\
\hline LTRIHR & -2.0729 & 2005.12-2009.12 & & $-6.0657 * *$ & 2002.03-2008.12 & \\
\hline LTRITH & -1.4941 & 2003.11-2009.12 & & -5.1775 & 2003.11-2010.11 & \\
\hline LRDK & -1.7298 & 2002.04-2009.03 & & -5.2343 & 2002.07-2007.02 & \\
\hline LTRINDP & $-4.2772 * *$ & 2007.11-2013.07 & & $-5.7670 * *$ & 2007.11-2009.09 & \\
\hline LWINDP & -2.5799 & 2008.11-2013.12 & & -4.9172 & $2008.06-2010-08$ & \\
\hline LiHR_BF & -1.9505 & 2008.06-2010.05 & & -4.1440 & 2002.11-2007.02 & \\
\hline LiTH_BF & -1.9281 & $2005.03-2007.03$ & & -4.4494 & $2004.06-2012.11$ & \\
\hline$\Delta$ LTRITH & $-6.0704^{*}$ & 2007.09-2010.03 & & $-14.4219 *$ & 2003.09-2013.07 & \multirow{5}{*}{$\begin{array}{cc}1 \% & -6.32 \\
5 \% & -5.73 \\
10 \% & -5.32\end{array}$} \\
\hline$\triangle$ LWINDP & $-7.0909 *$ & 2004.12-2009.01 & & $-15.7120^{*}$ & 2006.10-2009.01 & \\
\hline$\Delta$ LiHR_BF & $-9.0234^{*}$ & $2008.02-2009.08$ & & $-9.7591^{*}$ & 2008.06-2011.01 & \\
\hline$\Delta$ LITH_BF & $-6.0008^{*}$ & 2008.09-2013.11 & & $-13.4877^{*}$ & 2008.06-2011.03 & \\
\hline$\Delta \mathrm{LRDK}$ & $-9.9758^{*}$ & 2002.09-2008.02 & & $-10.2981^{*}$ & 2003.04-2006.11 & \\
\hline
\end{tabular}

-Test istatistiğine ilişkin kritik değerler Lee-Strazicich (2003)'ten elde edilmiştir. * \%1; ** \%5 ve *** \%10 anlamlılık düzeylerini göstermektedir.

Tablo 2'de çift kırılmaya izin veren Lee-Strazicich birim kök testi sonuçları verilmiştir. Sonuçlara göre serbest bölge ithalat ve ihracatı, Türkiye'nin ihracatı ve Türkiye'nin geliri serileri düzey değerlerinde durağanken; Türkiye'nin ithalatı, dünya gelirleri, ihracat ve ithalat birim fiyatları ile reel döviz kuru serileri birinci dereceden durağan çıkmıştır. Kırılma dönemlerine bakıldığında ise her serinin farklı dönemler için kırılmalara maruz kaldığı ve kriz etkilerinin net olarak gözükmediği için ihmal edilebileceği görülmektedir.

Tablo 1 ve tablo 2'de yer alan birim kök testi sonuçları birlikte değerlendirildiğinde, tüm değişkenlerin seviyede durağan olmadığı, birinci farkları alındığında ise serilerin durağan oldukları görülmektedir. Dolayısıyla değişkenler arasında eşbütünleşme ilişkisinin bulunup bulunmadığını görmek amacıyla uygun bir yöntem olarak ARDL yönteminin uygulanmasına geçilebilir.

\subsection{ARDL Yöntemi Sonuçları}

Bu çalışmada ARDL yönteminin uygulandığı 2 farklı modelde, çalışmanın asıı temasını oluşturan serbest bölge ithalatı(LSBITH) ve ihracatı(LSBIHR) ile Türkiye'nin ithalatı(LTRITH) ve ihracatı(LTRIHR) değişkenlerinin yanı sıra, dış ticaretti etkileyen diğer bazı değişkenler olarak reel efektif döviz kuru(LRDK), dünya gelirleri olarak dünyadaki endüstriyel üretim ${ }^{6}$ (LWiNDP), ithalat birim fiyatı(LiTH_BF), ihracat birim fiyatı(LiHR_BF) ve Türkiye'nin gelirini temsilen Türkiye'nin endüstriyel üretim(LTRINDP) verileri kullanılmıştır. Modeller kurulurken ARDL yönteminde Schwarz bilgi kriteri kullanılmış, maksimum gecikme uzunluğu 12 olarak seçilmiş ancak sistem tarafından otomatik belirlenmiş ve kovaryans matrisi katsayısı için HAC(Newey-West)

\footnotetext{
${ }^{6}$ Endürstriyel üretim endeksi; belirli imalat sanayilerinin belirli oranlarla üretimlerindeki artış ve azalışların hesaplanmasıyla oluşturulur.
} 
kullanılmıştır. Modeller hem sabit hem de trendli olarak seçilmiştir. Çalışmamızda kurulan modeller aşağıdaki şekilde gösterilebilir:

\section{Model 1: LTRITH $=\beta_{0}+\beta_{1} L S B I T H+\beta_{2} L R D K+\beta_{3} L \dot{I I T H} B B F+\beta_{4} L T R I N D P$ \\ Model 2: $L T R \mathbf{I} H R=\beta_{0}+\beta_{1} L S B \dot{I} H R+\beta_{2} L R D K+\beta_{3} L \mathbf{I} H R_{-} B F+\beta_{4} L W I N D P$}

Model 1: Model 1'de Türkiye ithalatının serbest bölge ithalatından etkilenip etkilenmediği araştırılmaktadır. Aşağıda oluşturulan Tablo 3, ARDL(12,3,0,0,12) modelinin tahmin sonuçlarını göstermektedir. Yapılan CUSUM testleri ${ }^{7}$ sonucunda modelde yapısal kırılma olduğu tespit edilmiş ve kukla değişken (DLTRITH) kullanılmıştır:

Tablo 3: ARDL Testi $(12,3,0,0,12)$ Modeli Tahmin Sonuçları

\begin{tabular}{|c|c|c|c|c|}
\hline Değişken & Katsayı & Std. Hata & T-istatistik & Olasılık \\
\hline LTRITH(-1) & 0.170852 & 0.056820 & 3.006912 & 0.0031 \\
\hline LTRITH(-12) & 0.446652 & 0.046810 & 9.541846 & 0.0000 \\
\hline LSBITH & 0.123518 & 0.030974 & 3.987785 & 0.0001 \\
\hline LSBITH(-1) & -0.029816 & 0.015709 & -1.897993 & 0.0597 \\
\hline LSBITH(-3) & -0.056169 & 0.019175 & -2.929317 & 0.0039 \\
\hline LRDK & 0.567547 & 0.062097 & 9.139685 & 0.0000 \\
\hline LITH_BF & 0.773905 & 0.091836 & 8.427019 & 0.0000 \\
\hline LTRINDP & 0.794408 & 0.134582 & 5.902789 & 0.0000 \\
\hline LTRINDP(-1) & -0.014521 & 0.105916 & -0.137096 & 0.8911 \\
\hline LTRINDP(-12) & -0.760180 & 0.102691 & -7.402590 & 0.0000 \\
\hline DLTRITH & -0.076868 & 0.015229 & -5.047493 & 0.0000 \\
\hline C & 6.306700 & 0.599532 & 10.51937 & 0.0000 \\
\hline \multicolumn{5}{|l|}{ Tanısal Testler } \\
\hline R2 & \multicolumn{2}{|c|}{0.995739} & Mean dependent var & 2363078 \\
\hline Düzeltilmiş R2 & \multicolumn{2}{|c|}{0.994812} & S.D. dependent var & 0.718178 \\
\hline Jarque-Bera & \multicolumn{2}{|c|}{$1.844686(0.397586)$} & Akaike Bilgi Kriteri & -2.921437 \\
\hline Breusch-Pagan-Godfrey & \multicolumn{2}{|c|}{$1.902448(0.1001)$} & Schwarz Bilgi Kriteri & -2.336062 \\
\hline Serial Correlation LM[12] & \multicolumn{2}{|c|}{$1.060281(0.2151)$} & Hannan-Quinn Kriteri & -2.684093 \\
\hline F-İstatistik & \multicolumn{2}{|c|}{$1073.587(0.000000)$} & Durbin-Watson stat & 1.794883 \\
\hline
\end{tabular}

*parantez içindeki veriler olasılık değerlerini, köşeli parantez içindeki veriler gecikme uzunluğunu temsil etmektedir.

Not: Tabloyu kısaltmak için her bir değişkenin sadece ilk ve sonuncu gecikme değerleri gösterilmiştir.

Tablo 3'de tanısal test sonuçları modelin uygunluğunu ortaya koymaktadır. Sonuçlar, modelin normal dağılım gösterdiğini, modelde otokorelasyon sorunu ve model kurma hatasının olmadığını göstermektedir. Dolayısıyla kurulan modelde yapısal kırılmanın bulunup bulunma-

\footnotetext{
${ }^{7}$ CUSUM testi, n gözlem kümesiyle ilişkili kümülatif hata terimlerine dayanmakta ve yüzde 5 anlamlılığı gösteren iki kritik doğru arasında çizilmektedir. Çizilen eğri, iki kritik sınır arasında yer alıyorsa, tahmin edilen katsayıların uzun dönemde istikrarlı olduğu kanaatine varılır (Altıntaş, 2008: 37-38).
} 
dığını test etmek amacıyla bir sonraki aşama olan CUSUM testine geçilebilir. Aşağıda yer alan Şekil 1 CUSUM test sonuçlarını göstermektedir.

Şekil 1: ARDL $(12,3,0,0,12)$ Modeli Yapısal Kırılma Bulunan CUSUM Grafiği*

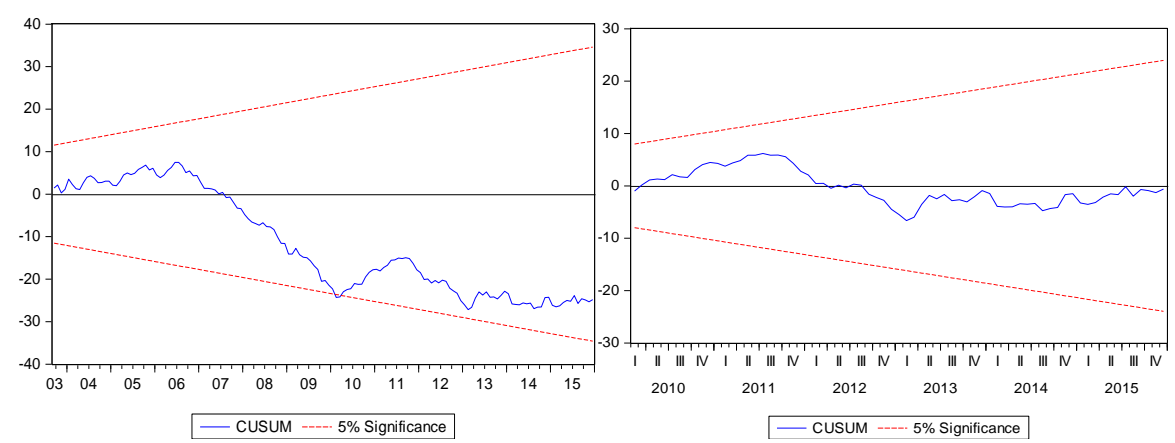

*Kesikli çizgiler yüzde 5 anlamlılık düzeyinde kritik sınırları, düz çizgiler ise CUSUM test değerlerini göstermektedir.

Şekil 1 incelendiğinde, modelde yapısal kırılma olduğu görülmektedir. Dolayısıyla modele 2010-1.2.3. ayları için kukla değişken eklenmiş ve kukla değişkenin yapısal kırılma problemini çözdüğü görülmektedir. CUSUM testi yapıldıktan sonra ARDL modeli sınır testine geçilebilir. Aşağıda oluşturulan Tablo 4 model 1 için ARDL sınır testi sonuçlarını göstermektedir.

Tablo 4: ARDL Testi $(12,3,0,0,12)$ Modeli Sınır Testi Sonuçları

\begin{tabular}{lll}
\hline Test İstatistiği & Değer & $\mathrm{K}$ \\
\hline F-istatistik & 23.71993 & 4 \\
\hline \hline & Kritik Değerler & \\
\cline { 2 - 3 } Anlam düzeyi & Alt Sınır I(0) & Üst Sınır I(1) \\
\hline \hline$\% 10$ & 2.45 & 3.52 \\
$\% 5$ & 2.86 & 4.01 \\
$\% 1$ & 3.74 & 5.06 \\
\hline
\end{tabular}

Tablo 4'de yer alan F-istatistik değeri, alt sınııın altındaysa ilişki yok, iki sınır arasında ise kararsızlık bölgesi, üst sınır değerlerinden yüksek olması durumunda ise modelde eşbütünleşme olduğunu göstermektedir. $k$ değeri ise modeldeki bağımsız değişken sayısını ifade etmektedir. Tablo 4'de yer alan F-istatistik değeri tablo kritik üst sınır değerinden yüksek olduğundan, modelde eşbütünleşme ilişkisinin bulunduğu sonucuna varılmaktadır. Söz konusu modelin kısa dönem katsayı sonuçları ise aşağıda Tablo 5'de gösterilmektedir. 
Tablo 5: ARDL Testi $(12,3,0$, 0, 12) Modeli Kısa Dönem Katsayı Sonuçları

\begin{tabular}{lllll}
\hline Değişken & Katsayı & Std. Hata & T-istatistik & Olasılık \\
\hline D(LTRITH(-1)) & -0.345730 & 0.049560 & -6.976002 & 0.0000 \\
D(LTRITH(-11)) & -0.446652 & 0.046810 & -9.541846 & 0.0000 \\
D(LSBITH) & 0.123518 & 0.030974 & 3.987785 & 0.0001 \\
D(LSBITH(-1)) & 0.048324 & 0.024500 & 1.972380 & 0.0504 \\
D(LSBITH(-2)) & 0.056169 & 0.019175 & 2.929317 & 0.0039 \\
D(LRDK) & 0.567547 & 0.062097 & 9.139685 & 0.0000 \\
D(LITH_BF) & 0.773905 & 0.091836 & 8.427019 & 0.0000 \\
D(LTRINDP) & 0.794408 & 0.134582 & 5.902789 & 0.0000 \\
D(LTRINDP(-1)) & -0.099289 & 0.139703 & -0.710713 & 0.4784 \\
D(LTRINDP(-11)) & 0.760180 & 0.102691 & 7.402590 & 0.0000 \\
D(DLTRiTH) & -0.076868 & 0.015229 & -5.047493 & 0.0000 \\
CointEq(-1) & -0.483418 & 0.058303 & -8.291419 & 0.0000 \\
\hline
\end{tabular}

Not: Tabloyu kısaltmak için her bir değişkenin sadece ilk ve sonuncu gecikme değerleri gösterilmiştir.

Tablo 5'de eşbütünleşme katsayısının negatif ve anlamlı olması beklenmektedir. Katsayı değerinin $-0,48$ olması bağımlı değişkene etki eden şokun bir sonraki dönemde \%48 oranında azalacağını, dengeden sapma olduğunda yaklaşık 2 dönemde tekrar dengeye geleceğini ve dolayısıyla eşbütünleşme ilişkisinin var olduğunu göstermektedir. Ayrıca, kısa dönemde serbest bölgelerin ithalatındaki \%1'lik değişme Türkiye'nin ithalatını \%0,12 oranında pozitif yönde, reel döviz kurundaki \%1'lik değişme Türkiye'nin ithalatını \%0,56 oranında pozitif yönde, ithalat birim fiyatındaki \%1'lik değişme Türkiye'nin ithalatını \%0,77 oranında pozitif yönde, Türkiye'nin endüstriyel üretimindeki \%1'lik değişme ise Türkiye'nin ithalatını \%0,79 oranında pozitif yönde etkilemektedir. Model 1 ile ilgili son olarak uzun dönem tahmin sonuçlarına bakılabilir. Bu amaçla aşağıda Tablo 6 oluşturulmuştur.

Tablo 6: ARDL Testi $(12,3,0,0,12)$ Modeli Uzun Dönem Tahmin Sonuçları

\begin{tabular}{lllll}
\hline Değişken & Katsayı & Std. Hata & T-istatistik & Olasılık \\
\hline LSBITH & -0.022320 & 0.059586 & -0.374584 & 0.7085 \\
LRDK & 1.174031 & 0.085012 & 13.810117 & 0.0000 \\
LITH_BF & 1.600903 & 0.127133 & 12.592314 & 0.0000 \\
LTRINDP & 0.738231 & 0.171342 & 4.308534 & 0.0000 \\
DLTRiTH & -0.159010 & 0.035631 & -4.462664 & 0.0000 \\
C & 13.046068 & 0.801197 & 16.283230 & 0.0000 \\
\hline
\end{tabular}

Tablo 6 incelendiğinde, uzun dönem tahmin sonuçlarına göre, Türkiye'nin ithalatı ile reel döviz kuru, Türkiye'nin endüstriyel üretimi ve ithalat birim fiyatı değerleri arasında hem iktisadi hem de istatistiksel olarak anlamlı bir ilişkinin bulunduğu sonucuna varılabilir. Uzun dönemde reel efektif döviz kurunda meydana gelecek \%1'lik bir artış Türkiye'nin ithalatında $\% 1,17$ 'lik bir artış sağlarken, Türkiye'nin endüstriyel üretimindeki \%1'lik artış ithalatı $\% 0,73$ ve ithalat birim fiyatındaki \%1'lik artış da ithalatı \%1,60 oranında pozitif yönde etkilemektir. Tab- 
lo değerlerine göre, serbest bölge ithalatı ile Türkiye'nin ithalatı arasında uzun dönemde anlamlı bir ilişki bulunmamıştır.

Model 2: Çalışmamızda oluşturulan Model 2'de Türkiye'nin ihracat hacminin serbest bölge ihracatından etkilenip etkilenmediği araştırılmaktadır. Bu amaçla oluşturulan Tablo 7'da $\operatorname{ARDL}(2,2,0,0,0)$ modeli tahmin sonuçları yer almaktadır.

Tablo 7: ARDL Testi $(2,2,0,0,0)$ Modeli Tahmin Sonuçları

\begin{tabular}{lllll}
\hline Değişken & Katsayı & Std. Hata & T-isstatistik & Olasılık \\
\hline LTRIHR(-1) & 0.216666 & 0.058272 & 3.718168 & 0.0003 \\
LTRIHR(-2) & 0.158363 & 0.060714 & 2.608324 & 0.0099 \\
LSBIHR & 0.471311 & 0.038245 & 1.232330 & 0.0000 \\
LSBIHR(-1) & -0.229070 & 0.038495 & -5.950644 & 0.0000 \\
LSBIHR(-2) & -0.154469 & 0.045291 & -3.410612 & 0.0008 \\
LRDK & 0.648849 & 0.064060 & 1.012877 & 0.0000 \\
LIHR_BF & 0.860787 & 0.101513 & 8.479590 & 0.0000 \\
LWINDP & 0.503199 & 0.169513 & 2.968506 & 0.0034 \\
C & 4.329519 & 1.264 .091 & 3.425005 & 0.0008 \\
@TREND & 0.002260 & 0.000316 & 7.158846 & 0.0000 \\
\hline
\end{tabular}

\begin{tabular}{llll}
\hline Tanısal Testler & & & \\
\hline R2 & 0.994959 & Mean dependent var & 2.309514 \\
Düzeltilmiş R2 & 0.994707 & S.D. dependent var & 0.811775 \\
Jarque-Bera & $4.477548(0.106589)$ & Akaike info criterion & -2.769315 \\
Breusch-Pagan-Godfrey & $0.024622(0.9741)$ & Schwarz criterion & -2.598419 \\
Serial Correlation LM[12] & $0.947829(0.3338)$ & Hannan-Quinn criter. & -2.700087 \\
F-İstatistik & $3.947322(0.000000)$ & Durbin-Watson stat & 1.992675 \\
\hline
\end{tabular}

*parantez içindeki veriler olasılık değerlerini, köşeli parantez içindeki veriler gecikme uzunluğunu temsil etmektedir.

Tablo 7'da tanısal test sonuçları modelin uygunluğunu ortaya koymaktadır. Ulaşılan sonuçlar, modelin normal dağılım gösterdiğini, modelde otokorelasyon sorunu ve model kurma hatasının olmadığını göstermektedir. Kurulan modelde yapısal kırılmanın bulunup bulunmadığını test etmek amacıyla aşağıda Şekil 2'de CUSUM test sonuçları yer almaktadır. 
Şekil 2: ARDL Testi (2, 2, 0, 0, 0) Modeli CUSUM Grafiği

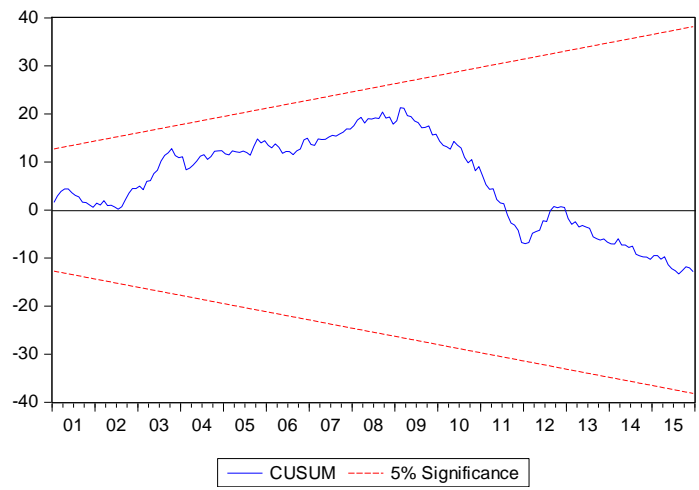

Şekil 2 incelendiğinde, yapılan CUSUM test sonuçlarına göre modelde yapısal kırılma bulunmadığı görülmektedir. Bu nedenle herhangi bir kukla değişken kullanmadan ARDL modeli sınır testine geçilebilir. Aşağıda oluşturulan Tablo 8 model 2 için ARDL sınır testi sonuçlarını göstermektedir.

Tablo 8: ARDL Testi $(2,2,0,0,0)$ Modeli Sınır Testi Tahmin Sonuçları

\begin{tabular}{lll}
\hline Test İstatistiği & Değer & $k$ \\
\hline F-istatistik & 12.44385 & 4 \\
\hline \hline \multirow{2}{*}{ Anlam düzeyi } & Kritik Değerler & \\
\cline { 2 - 3 } & Alt Sınır I(0) & Üst Sınır I(1) \\
\hline \hline \%10 & 3.03 & 4.06 \\
$\% 5$ & 3.47 & 4.57 \\
$\% 1$ & 4.4 & 5.72 \\
\hline
\end{tabular}

Tablo 8'de yer alan $\mathrm{F}$ istatistik değeri tablo kritik üst sınır değerlerinden yüksek olduğundan, modelde eşbütünleşme ilişkisinin bulunduğu sonucuna varılmaktadır. Söz konusu modelin kısa dönem katsayı tahmin sonuçları ise aşağıda tablo 9'de gösterilmektedir.

Tablo 9: ARDL Testi (2, 2, 0, 0, 0) Modeli Kısa Dönem Katsayı Sonuçları

\begin{tabular}{lllll}
\hline Değişken & Katsayı & Std. Hata & T-istatistik & Olasılık \\
\hline D(LTRIHR(-1)) & -0.158363 & 0.060714 & -2.608324 & 0.0099 \\
D(LSBIHR) & 0.471311 & 0.038245 & 12.323304 & 0.0000 \\
D(LSBIHR(-1)) & 0.154469 & 0.045291 & 3.410612 & 0.0008 \\
DLRDK & 0.648849 & 0.064060 & 10.128766 & 0.0000 \\
D(LIHR_BF) & 0.860787 & 0.101513 & 8.479590 & 0.0000 \\
DLWINDP & 0.503199 & 0.169513 & 2.968506 & 0.0034 \\
D(@TREND()) & 0.002260 & 0.000316 & 7.158846 & 0.0000 \\
CointEq(-1) & -0.624971 & 0.052236 & -11.964355 & 0.0000 \\
\hline
\end{tabular}


Tablo 9 incelendiğinde; katsayı değerinin -0,62 olması, bağımlı değişkene etki eden bir şokun bir sonraki dönemde \%62 oranında azalacağını, dengeden sapma olduğunda yaklaşık 1,5 dönemde tekrar dengeye gelineceğini ve dolayısıyla eşbütünleşme ilişkisinin var olduğunu göstermektedir. Tablo değerlerine göre ayrıca, kısa dönemde serbest bölgelerin ihracatındaki \%1'lik değişme Türkiye'nin ihracatını \%0,47 oranında pozitif yönde, reel döviz kurundaki \%1'lik değişme Türkiye'nin ihracatını \%0,64 oranında pozitif yönde, ihracat birim fiyatındaki \%1'lik değişme Türkiye'nin ihracatını \%0,86 oranında pozitif yönde ve dünyadaki endüstriyel üretimdeki \%1'lik değişme Türkiye'nin ihracatını \%0,50 oranında pozitif yönde etkilemektedir. Model 2'nin uzun dönem tahmin sonuçlarına bakmak için ise Tablo 10 oluşturulmuştur.

Tablo 10'da yer alan uzun dönem tahmin sonuçlarına bakıldığında, Türkiye'nin ihracatı ile serbest bölgelerin ihracatı, reel döviz kuru, ihracat birim fiyat değeri ve dünya gelirleri arasında hem iktisadi hem de istatistiksel olarak anlamlı ve pozitif yönlü bir ilişkinin bulunduğu sonucuna varılmaktadır. Uzun dönemde serbest bölgelerin ihracatındaki \%1'lik değişme Türkiye ihracatında \%0,14, reel efektif döviz kurunda meydana gelecek \%1'lik bir değişme Türkiye'nin ihracatında \%1,03, ihracat birim fiyatındaki \%1'lik değişme Türkiye'nin ihracatında \%1,37 ve dünya gelirlerindeki \%1'lik değişme ise Türkiye'nin ihracatında \%0,80'lik artışa neden olmaktadır.

Tablo 10: ARDL Testi (2, 2, 0, 0, 0) Modeli Uzun Dönem Tahmin Sonuçları

\begin{tabular}{lllll}
\hline Değişken & Katsayı & Std. Hata & T-istatistik & Olasılık \\
\hline LSBIHR & 0.140441 & 0.040605 & 3.458747 & 0.0007 \\
LRDK & 1.038207 & 0.074172 & 13.997219 & 0.0000 \\
LIHR_BF & 1.377323 & 0.112589 & 12.233177 & 0.0000 \\
LWINDP & 0.805156 & 0.284944 & 2.825667 & 0.0053 \\
C & 6.927552 & 1.789960 & 3.870228 & 0.0002 \\
@TREND & 0.003616 & 0.000395 & 9.145863 & 0.0000 \\
\hline
\end{tabular}

\section{Sonuç ve Değerlendirme}

Türkiye gibi gelişmekte olan ülkelerde, iktisadi kalkınmanın finansmanını sağlamak için, ihtiyaç duyulan sermayeyi temin etmenin en önemli yollarından biri dış ticarette avantajlar sağlamaktır. Dış ticarette avantaj sağlamanın en önemli araçlardan biri ise serbest bölge uygulamalarıdır. Bu bağlamda Türkiye'de de 1987'den beri serbest bölgeler kurulmuş ve söz konusu bölgeler dış ticareti geliştirmenin önemli bir aracı olarak görülmüştür.

Serbest bölgeler hem ihracat hem de ithalat üzerinde oluşturdukları avantajlarla dış ticareti olumlu yönde etkileyebilmektedir. Buna göre ihracat üzerindeki etkileri genellikle ana ülkeden serbest bölgelere gerçekleşen hammadde, mamul, yarı mamul ve diğer girdi ihracatı noktalarına yoğunlaşırken, ithalat üzerindeki etkileri ise, daha çok yurt içinde ihtiyaç duyulan her türlü mal ve girdinin serbest bölgelerden daha kolay bir şekilde temin edilebilmesi noktasına yoğunlaşmaktadır. Ancak burada belirtilen etkiler aynı zamanda diğer yurtiçi yatırımları da olumlu etkilemekte ve ülkenin dış ticaret kapasitesini daha da genişletmektedir. Bu bağlamda serbest bölgelerin dış ticaret üzerindeki etkilerinin analiz edilebilmesi amacıyla ekonometrik bir yöntem olan ARDL yöntemi kullanılmış ve Türkiye için hem kısa dönem hem de uzun dönem eşbütünleşme analizi gerçekleştirilmiştir. 
Yapılan eşbütünleşme testi sonuçlarına göre; kısa dönemli değişmelere bakıldığında Türkiye'nin ithalatı; serbest bölgelerin ithalatından (serbest bölgelerin ithalatındaki \%1'lik değişme Türkiye'nin ithalatını \%0,12 oranında), reel döviz kurundan, ithalat birim fiyatından ve Türkiye'nin endüstriyel üretiminden pozitif yönde etkilenmektedir. Türkiye'nin ihracatı ise; serbest bölgelerin ihracatından (serbest bölgelerin ihracatındaki \%1'lik değişme Türkiye'nin ihracatını $\% 0,47$ oranında), reel döviz kurundan, ihracat birim fiyatından ve dünyadaki endüstriyel üretimden pozitif yönde etkilemektedir.

Uzun dönem analiz sonuçlarına bakıldığında; Türkiye'nin ithalatının reel döviz kuru, Türkiye'nin geliri ve ithalat birim fiyatından etkilenirken, serbest bölge ithalatından etkilenmediği (iki değişken arasındaki ilişki istatistiksel olarak anlamsız bulunmuştur) görülmektedir. Türkiye'nin ihracatı için yapılan analiz sonuçlarına bakıldığında ise, ülke ihracatının serbest bölgelerin ihracatından (serbest bölgelerin ihracatındaki \%1'lik değişme Türkiye ihracatını \%0,14 oranında), reel döviz kurundan, ihracat birim fiyatından ve dünya gelirlerinden pozitif yönde etkilendiği gözlenmiştir.

Ulaşılan analiz sonuçları değerlendirildiğinde, genel olarak literatür ile uyumlu sonuçlara ulaşıldığı görülmektedir. Nitekim, Khalifa (tarihsiz), Jenkins (2005), Tiefenbrun (2013), VicensFeliberty (2013), Siroen ve Yücer (2014), Karaduman ve Yıldız (2002), Uzandaç (2002), Kavlak (2012) ve Bakan ve Gökmen (2014) çalışmalarında serbest bölge ticaretinin (özellikle ihracat açısından) ülke dış ticaretini olumlu etkilediğine vurgu yapmışlardır. Bu bağlamda Türkiye'yi ele alması ve ekonometrik analiz kullanması bakımından çalışmamıza yakın bir çalışma olan Uzandaç (2008), serbest bölge ihracatının etkisini \%0,30 ölçerken, çalışmamızda kısa dönem için bu sonuç \%0,47 ve uzun dönem için ise \%0,14 olarak bulunmuştur. Dolayısıyla Türkiye için serbest bölgelerin özellikle ihracatı artırma yönünde önemli bir potansiyele sahip oldukları sonucuna varılabilir. Bu potansiyeli daha iyi kullanmak amacıyla söz konusu bölgelerin daha işlevsel hale getirilmeleri ve bunu gerçekleştirmek için mevcut yasal ve kurumsal düzenlemelerin gözden geçirilerek, hem ihracatçı hem de ithalatçının ihtiyaçlarına hızlı bir şekilde cevap verebilecek düzenlemelerin hayata geçirilmesi önemli görülmektedir. Dünya ticaret hacminin giderek arttığı durumu da göz önüne alındığında, Türkiye'de üretim, istihdam ve dış ticarete katkı sunabilecek yeni serbest bölgelerin kurulması veya mevcut serbest bölge uygulamalarının kapsamlarının genişletilmesi suretiyle daha etkin hale getirilmeleri bu bağlamda sunulabilecek diğer öneriler arasında yer almaktadır. 


\section{Kaynaklar}

ALAM, I. ve R. QUAZi (2003), “Determinants of Capital Flight: an Econometric Case Study of Bangladesh", International Review of Applied Economics, 17 (1), 85-103. http://www.tandfonline.com/doi/pdf/10.1080/713673164, 12.05.2016.

ALTıNTAŞ, H. (2008), “Türkiye'de Para Talebinin İstikrarı ve Sınır Testi Yaklaşımıyla Öngörülmesi: 1985:2006” Erciyes Üniversitesi iiBF Dergisi, Sayı:30, Ocak-Haziran 2008, 15-46.

ASLAN, N. (2013), Serbest Bölgelerin Karadeniz Ticaretine Etkisi, Yayınlanmamış Yüksek Lisans Tezi, Malatya İnönü Üniversitesi SBE.

BAĞRIAÇıK, A. (1983), “Türkiye'de Serbest Bölge Uygulaması”, Yeni İş Dünyası, Sayı 47, 20-28

BAKAN, S. ve GÖKMEN S. (2014), "Serbest Bölgeler ve Dış Ticaret İlişkisi: Gaziantep Serbest Bölgesi Örneği", Electronic Journal Of Social Sciences, 13(51), 34-51.

BOZKURT, H. (2007), Zaman Serileri Analizi, Bursa: Ekin Kitap Evi.

DARNELL, A. C. (1994), A Dictionary of Econometrics, Vermont, USA: Edward Elgar Pub.

DEMIRTAŞ, Ş. C. (2016), Serbest Bölgelerin Dış Ticarete Etkileri: Türkiye Üzerine Ampirik Bir Analiz, Sakarya Üniversitesi, Yayınlanmamış Yüksek Lisans Tezi, Sakarya.

GRANGER, C. WJ, and P. NEWBOLD (1974), "Spurious Regressions in Econometrics" Journal of Econometrics, 2(2), 111-120.

HAO, S. (2010), "Study on Relationship Between Trade Development of Waigaoqiao Free Trade Zone and Economic Growth in Shanghai", Orient Academıc Forum, 61-64.

INCEKARA, A. (1986), Dünyada ve Türkiye'de Serbest Bölgeler Uygulaması-Mevzuatı, İstanbul:Temel Yayınları.

JAYANTHAKUMARAN, K. (2003), "Benefit-Cost Appraisals of Export Processing Zones: A Survey of the Literature", Development Policy Review, 21 (1), 51-65.

JenkinS, M. (2005), Economic and Social Effects of Export Processing Zones in Costa Rica, Working Paper No:97, Geneva: International Labour Office, http://ilo.org/wcmsp5/groups/public/---ed_emp/---emp_ent/--multi/documents/publication/wcms_101038.pdf, 23.06.2016

KARADUMAN, N. ve YILDIZ Z. (2002), "Serbest Bölge Uygulamalarının Dış Ticarete ve Yabancı Sermayeye Katkıları" Süleyman Demirel Üniversitesi İktisadi ve İdari Bilimler Fakültesi Dergisi, Sayı 7(1), 133-152.

KAVLAK, M. E. (2012), Economıc Impacts of Free Zones In Turkey: A Questıonnaıre Study Conducted with Firms Operatıng in Turkısh Free Zones Regardıng The Perceptıon Of The Fırms On The Success Of Free Zones, Orta Doğu Teknik Üniversitesi Yayınlanmamış Doktora Tezi, Ankara.

KENNEDY, P. (2006). Ekonometri Kılavuzu, Çev.Ed. Muzaffer Sarımeseli ve Senay Açıkgöz, Ankara:Gazi Kitabevi.

KHALIFA, M. M (tarihsiz), "Evaluation of the Role of the Free Zones in Egypt in Developing Exports and Attracting Foreign Investments", Partnership in Development Research Briefs, No: 21. http://www1.aucegypt.edu/src/pdr/Research_Briefs/021_Magdi_Khalifa.pdf, 25.05.2016.

LEE, J., \& STRAZiCiCH, M. C. (2003), "Minimum Lagrange multiplier unit root test with two structural breaks." Review of Economics and Statistics, 85(4), 1082-1089.

NARAYAN, P. K. and NARAYAN, S. (2005), "Estimating Income and Price Elasticities of Imports for Fiji in a Cointegration Framework", $\quad$ Economic Modelling, 22 (3), 423-428, http://www.sciencedirect.com/science/article/pii/S0264999304000495, 15.05.2016.

NARAYAN, P. K. and R. SMYTH (2006), "What Determines Migration Flows from Low-Income to High-Income Countries? An Empirical Investigation of Fiji-U.S. Migration 1972-2001", Contemporary Economic Policy, 24 (2), 332342, http://onlinelibrary.wiley.com/doi/10.1093/cep/byj019/pdf, 12.05.2016

OECD (2016), "Free Zones: Benefits Costs", http://www.oecdobserver.org/news/archivestory.php/aid/3101/Free_zones:_Benefits_and_costs.html\#sthash.Q Fs3Di0D.dpuf, 21.06.2016.

ÖZŞAHIN, Ş. (2012), “Türkiye Ekonomisinde Finansal Liberalizasyon ve Ekonomik Büyüme Etkileşiminin ARDL Yöntemi İle Analizi”, SÜ iiBF Sosyal ve Ekonomik Araştırmalar Dergisi, (23), 379-413.

PESARAN, M. H. and B. PESARAN (1997), Working with Microfit 4.0: Interactive Econometric Analysis, , Oxford University Press., http://www.oup.com/

PESARAN, M.H., Y. SHIN and R.J. SMITH (2001), "Bounds Testing Approaches to the Analysis of Level Relationships", Journal of Applied Econometrics, 16(3), 289-326. 
PHILLIPS, P.C.B. and PERRON, P. (1988), "Testing for a Unit Root in Time Series Regressions", Biometrica, 75, 335-346.

SHIN, Y., and PESARAN, M. H. (1999), “An Autoregressive Distributed Lag Modelling Approach to Cointegration Analysis", in S. Strom (Ed.), Econometrics and Economic Theory in the 20th century: The Ragnar Frish Centennial Symposium. Cambridge: Cambridge University Press. 371-413.

SEVÜLTEKiN, M. ve NARGELEÇEKENLER, M. (2005), Zaman Serileri Analizi, Ankara: Nobel Yayın Dağıtım.

SIROEN, J. M. and YÜCER A. (2014), "Trade Performance of Free Trade Zones”, Document De Travail, No.DT/2014/09, 1-28.

T.C. EKONOMI BAKANLIĞI (2016a), Serbest Bölgeler, http://www.ekonomi.gov.tr, 21.06.2016.

T.C. EKONOMI BAKANLIĞI (2016b), Serbest Bölgeler Kanunu, http://www.ekonomi.gov.tr, 21.06.2016.

TETSU, K. (2006), "Regional Development and Rural-based Export Processing Zones in Developing Countries", International Economic Journal, Vol.20, No:3, 369-383.

TEYLER, W.G. and A.C.A. NEGRETE (2009), "Economic Growth and Export Processing Zones: An Empirical Analysis of Policies to Cope with Dutch Disease", LASA Congress, Rio de Janeiro, June 11-14, 2009.

TiEFENBRUN, S. (2013), "U.S. Foreign Trade Zones of the United States, Free-Trade Zones of the World, and their Impact on the Economy", Journal of International Business and Law, Vol.12: No:2, 148-222.

TÜMENBATUR, A. (2012), "Serbest Bölgeler ve Türkiye Ekonomisine Katkıları Üzerine Bir Değerlendirme”, Ç.Ü. Sosyal Bilimler Enstitüsü Dergisi, Cilt:21, Sayı:3, 339-356.

UÇKUN, G., A. ÖNCEL ve O. ÖZER (2005), “Dış Ticaret Açısından Serbest Bölge Avantajları ve Türkiye'deki Mevcut Durumun Değerlendirilmesi”, Plastik Araştırma, Geliştirme ve İnceleme Dergisi, Cilt 79, 122-126.

UZANDAÇ, H. G. (2008), Serbest Bölgelerin Dış Ticaret Üzerindeki Etkileri: Türkiye Uygulaması, Yayınlanmamış Yüksek Lisans Tezi, Erciyes Üniversitesi Sosyal Bilimler Enstitüsü.

VICENS-FELIBERTY, M.A. (2013), The Performance of the United States Foreign Trade Zones and Their Impact on Export Intensit (A Panel Data Approach), New Mexico State University, http://search.proquest.com/docview/1449802170.

WiKiPEDiA.org, https://en.wikipedia.org/wiki/Free_trade_zone, 15.06.2016

YILANCI, V. (2012), “Türkiye'de Para Talebi İstikrarlılığının Testi: Kayan Pencerelerde Sınır Testi Yaklaşımı”, Dumlupınar Üniversitesi Sosyal Bilimler Enstitüsü Dergisi, Sayı:33, Ağustos 2012, 67-74. 